\title{
Determinants of decision-making and patient participation in paediatric clinical trials: A literature review
}

\author{
Falk Wulf, Marta Krasuska, Monika Bullinger \\ Center for Psychosocial Medicine, University Medical Center Hamburg-Eppendorf, Hamburg, Germany \\ Email: f.wulf@uke.uni-hamburg.de
}

Received 30 April 2011; revised 20 September 2011; accepted 25 October 2011

\begin{abstract}
Background: Studies have shown that many drugs used in children may not have been authorised for use in this age group. This poses significant risks on children. A new EU regulation came into effect in 2007 to ensure that medicinal products that are researched, developed and authorised will also meet the therapeutic needs of children. This will mean an increased demand for children to participate in clinical trials. Objectives: To identify the needs and motivations of children and their families who have participated, might participate or declined to participate in clinical trials. Methods: We did a literature search and reviewed empirical studies which examined eligible outcomes. The findings of these studies were analyzed in a broad qualitative and descriptive bottom-up process. Results: We found that the understanding of advanced concepts of research such as randomisation is often insufficient. The needs of families affected by a serious disease are not addressed explicitly. Personal benefit and altruistic motives were two important reasons for participation. Conclusions: The comprehension of information given in the consent process should be secured by improving the information material. The communication process should be more mutual. Children and their families should be empowered to address their needs in the process of considering participation in a clinical trial.
\end{abstract}

Keywords: Clinical Trial; Child; Needs; Motives; Empowerment; Literature Review

\section{INTRODUCTION}

Research is a central issue of medical progress. And children have the right to benefit from the state-of-the-art medical treatment and interventions. Until very recently research targeting paediatric population were largely unavailable. For this reason decisions on medical treatment were often based on the results of research conducted with adult population. Although differences in treatment effects between young and adult patients are well known, there were fewer clinical trials than needed to adequately evaluate the effects of new medicine in children. This was due to the lack of appropriate regulations for the conduct of paediatric clinical trials, especially with regard to ethical considerations [1].

The lack of clinical trials so far has prevented paediatricians from making evidence-based treatment recommendations and deprived their young patients of potentially useful therapies [2,3]. This situation has recently changed. The discussion about optimal drug therapies for children resulted in several initiatives in Europe and other non-European countries with the aim of providing better medical care for children. With the Paediatric regulation (EC) No 1901/2006 [4] requiring sound scientific evidence for treatment benefits in children and adolescents, it is now obligatory to conduct paediatric clinical trials to test medications for use in children and adolescents.

Within this new regulation, prerequisites for designing, conducting and reporting clinical paediatric trials are specified, which comply with the principles of good clinical and scientific practice [5]. Good Clinical Practice (GCP) guidelines and standard operating procedures (SOPs) ensure that ethics committee approval and informed consent are obtained, that trials are well-designed and monitored to reduce risks and that appropriate statistical analysis strategies are followed.

The Clinical Trials Directive 2001/20/EC [6] and the subsequent recommendation for the implementation of this directive [7] provide guidelines with regards to the rights of the child and its caregivers as well as the information given to potential participants about the study which is crucial for families and patients to decide whether to enter a clinical trial or not.

The regulatory and ethical aspects although of prime importance are not the focus of this paper. These issues are extensively examined in recent literature reviews $[8,9]$.

However, conducting state-of-the-art paediatric clinical trials depends not only on appropriate legislations 
and guidelines, but also on the decision of patients and families to participate or not, and then on acting upon this decision. As the literature on decision making in medicine shows, many factors are expected to play a role in this process [10]. It is essential to acknowledge that participation or non-participation in a trial is a psychological process involving a basic understanding of a person's (child, adolescent and their parents) behaviour in terms of cognition and action.

In order to advance understanding of determinants of patient participation in paediatric clinical trials, a literature review was conducted addressing consent to and participation in clinical trials from the perspective of the young patients, their families and their physicians.

The aims of this literature review were to explore the comprehension of information materials, the process of decision-making and the reasons for participation or withdrawal which we define as the "core factors" (see Figure 1).

Based on the results of our review we would like to provide suggestions for empowering families and chil-

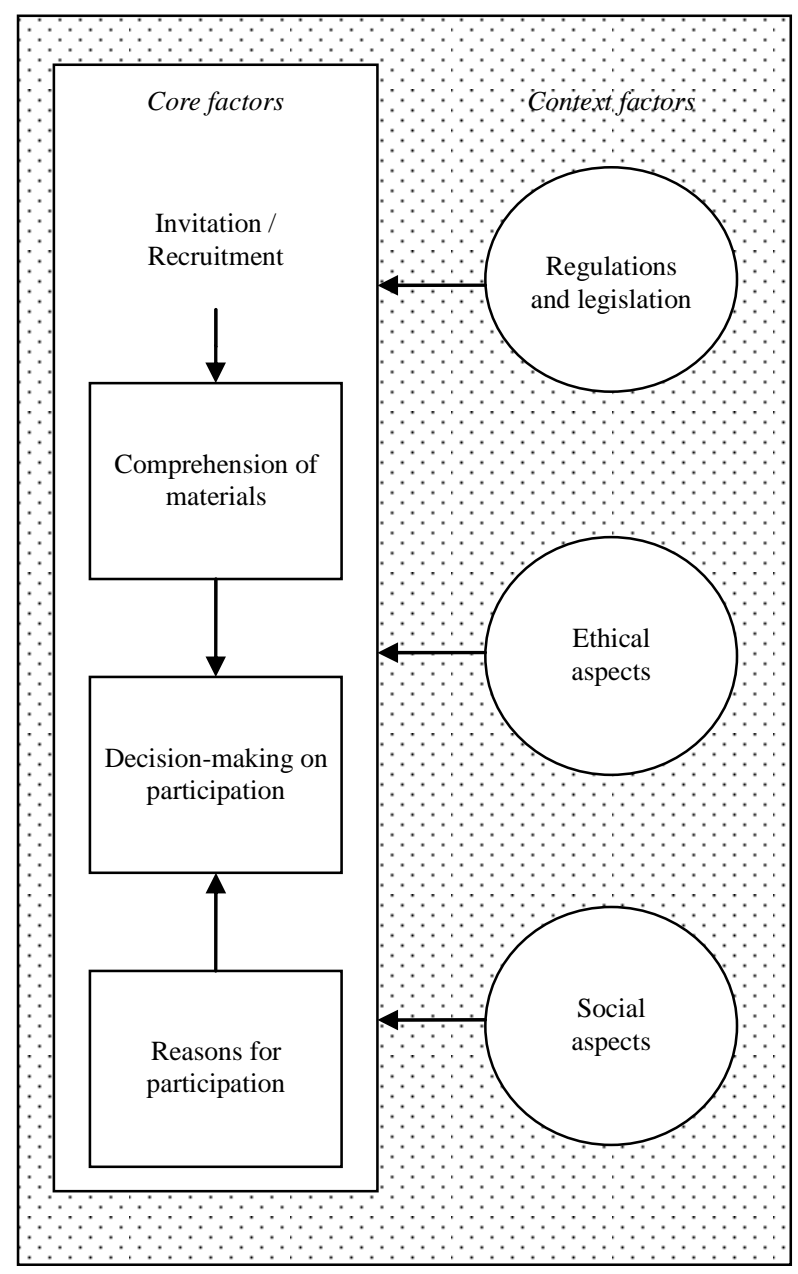

Figure 1. Proposed factors determining participation in clinical trials. dren participating in future clinical research.

\section{METHODS}

\subsection{Search Strategy}

A systematic literature search on children's participation in clinical trials was conducted to identify studies that examine psychological aspects related to children's participation in clinical trials. To approach this complex research field we decided to use a broad search strategy to identify studies which address any aspect of child participation in clinical trials. We collected data sources that were published between January 1998 and December 2010 based on a computerized search of MEDLINE, MEDLINE in-Process, EMBASE and current contents.

The following search strategies were used:

Search 1: "((consent OR assent) AND ((child* OR infant* OR neonat* OR adolesc* OR p*diatr*) AND clinic* trial*)).ti,ab”. This search yielded a list of 495 results; after removing the duplicates 288 results remained in the list.

Search 2: “((participation OR recruitment) AND ((child* OR infant* OR neonat* OR adolesc* OR p* diatr*) AND clinic* trial*)).ti,ab”. This search yielded a list of 754 results; after removing the duplicates 443 results remained in the list.

Within each search, titles and abstracts were initially screened for relevance. Further a careful examination of all abstracts was performed in order to identify terms related to decisions of children's participation in clinical trials. In a second phase full texts of potentially relevant studies were retrieved and examined using a priori defined inclusion criteria (IC, see Table 1). Finally further papers were identified from the reference lists of relevant articles. Only research reports in English were considered.

The process of study selection is shown in Figure 2.

Clinical trials were excluded if they enrolled only adults or mothers in the decision process as participants and if they stated that they only gained the approval of the ethics committee.

Also excluded were review articles, essays and articles focusing on legal, regulatory or ethical aspects.

Using the formalized search strategies and comparing the listings for multiple appearances resulted in a baseline set of articles which were obtained as full text versions and were reviewed by two authors (FW and MK). A third reviewer was consulted to help resolve differences (MB). An overview of the articles is presented in the appendix.

\section{RESULTS}

Because of the complexity of the subject and the lack of comparable studies a theoretical approach was chosen according to stages of patient involvement in a trial: 1) 
Table 1. Inclusion criteria (IC).
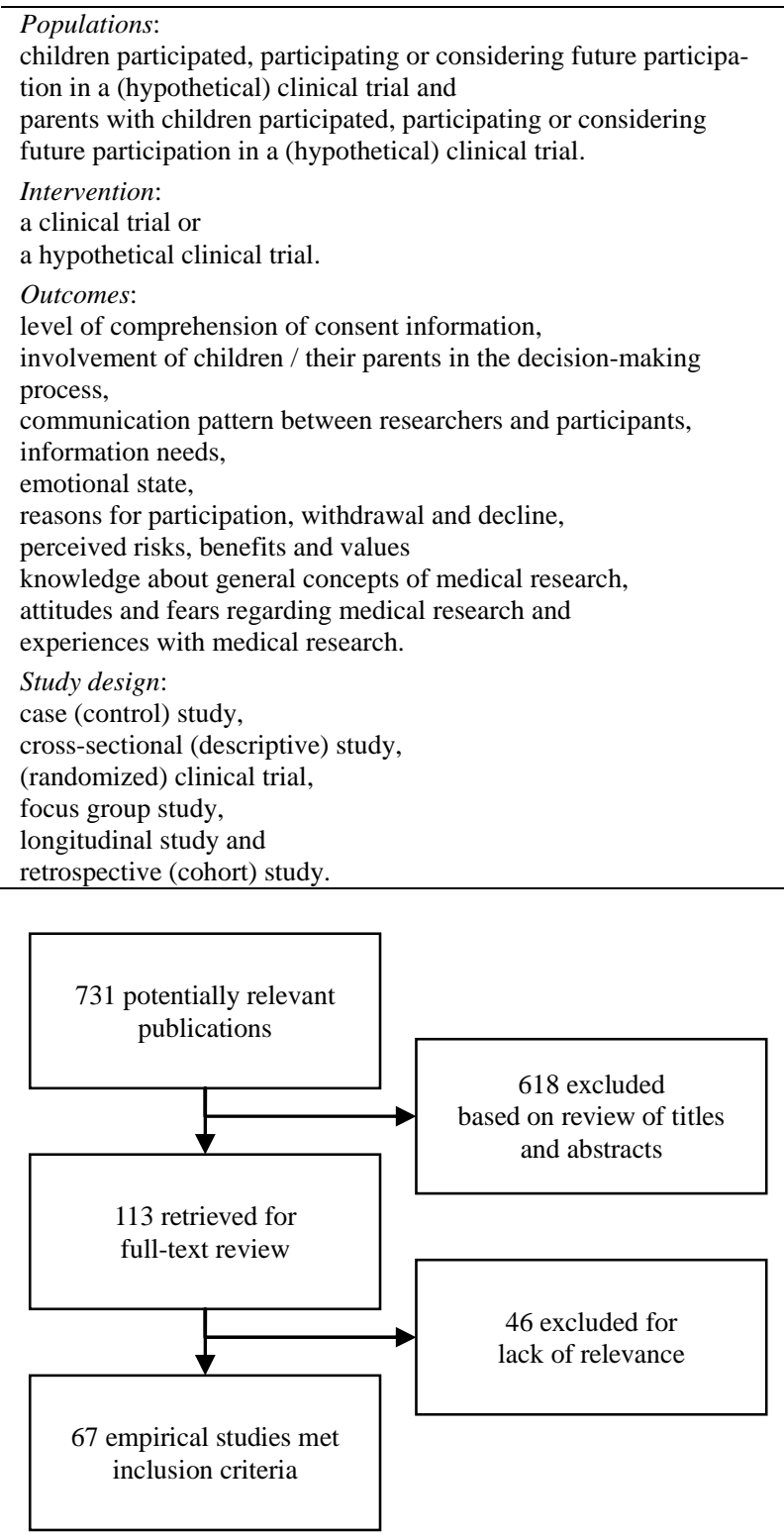

Figure 2. Selection of research reports.

understanding the implications of participation, 2) the decision-making process and 3) the act of participation. In total we identified 67 papers of which 42 refer to the cluster "Understanding", 30 to the cluster "Decision making" and 31 to the cluster "Participation" (several publications are related to more than one cluster, see the table in the Appendix).

\subsection{Comprehension: Understanding the Implications of Participating in a Clinical Trial}

\subsubsection{General}

A well-designed assent and consent form should ensure a freedom of choice regarding participation in a clinical trial (CT) and a comprehensive understanding of all possible risks and benefits of participation.

Giving consent or assent to participation in medical research is more than simply signing a document. It is an interactive process, which begins when parents and the young patient are first approached by their physician. Timing of this approach as well as the characteristics of the situation impact on the amount as well as the level of information that parents and children are able to understand and remember [11-14].

Especially in emergency situations, communication often takes place in a highly stressful situational context which is likely to constrain physician-parent communication and limit potential understanding $[11,12,15]$. If parents and children are not given written and oral information in their first language or if the information provided is of poor linguistic quality, their chances to fully understand what the research is about are lower [16].

\subsubsection{Children's Comprehension}

In general, children's ability to understand the information given before consent or assent depends on their age [17]. From the age of seven to nine years, appropriate understanding is possible [18,19]. However, understanding depends not only on the age but also on previous experiences related to diagnosis, treatment and earlier experience with research $[18,20]$. Children experienced with the healthcare system tend to understand more of the trial situation than their healthy counterparts [20]. Careful design of the assent documents in an ageappropriate way can enhance understanding [21]. Also, children's participation in designing the documents can improve the subsequent comprehension and assent [22]. It should be noted however that, in comparison to adults, children's understanding of their specific health conditions, of the global concept of illness and of medical research is more basic and improves with maturation $[18,23]$. Specifically, the concept of treatment alternatives, the duration of participation, the right to withdraw and the voluntary nature of participation seem to be difficult to understand $[23,24]$ even if the potential participants were adolescents [25].

\subsubsection{Parent's Comprehension}

Although parents' level of understanding is assumed to be generally higher than that of their child due to higher cognitive abilities, still it might be restrained by factors relating to the situation and to parental characteristics. For example: some parents may enrol their children in a CT without fully understanding the implications because of their limited language competence [26].

Comparing alternative ways of presenting consent in- 
formation to parents in a study, no significant difference was found between written forms, written forms enhanced for better readability, videotape and self-paced PowerPoint presentations in terms of understanding the consent process, however there was a trend for poorer readers to have better understanding with the enhanced written material [27]. Another study found that parents who received a consent form which was improved for better readability, had a better understanding of risks, benefits and characteristics of the study design, even though parents significantly overestimated their understanding [28]. In another study parents reported that material provided on DVD for home use has made it easier to understand the information that the physician later provided [29].

A sequential approach to providing information showed evidence that such a staged procedure improved parents' understanding of the purpose and conduct of the trial $[11,30]$.

Parents who had read the consent form and received additional oral explanation were better at understanding risks and procedures in clinical trials [13,31,32].

Parents' appraisal of medical research in general and participation of their children in a study appears to be mostly positive or neutral $[15,33,34]$.

The process of understanding and giving consent differs between adults deciding about their own participation and adults deciding on the behalf of their children: parents making health decisions for their children may experience particular difficulties in understanding the complex information in order to feel able to sign the consent form [33,35].

Parents' understanding of available alternative treatment options is often poor and parents see no possibility to discuss whether or not to join a RCT [36-38]. Especially mothers tend to refrain from a clear distinction between discussing possible participation in clinical trial and discussing their child's treatment options. As a result, treatment and research appear inseparable to mothers of children participating in a clinical trial $[37,39]$. In the decision-making process, parents potentially fail to grasp the distinction between the imperatives of clinical research and of ordinary treatment. This "therapeutic misconception" may lead to higher participation rates because the parents or patients sign the consent forms with an only modest appreciation of risks and disadvantages of participation [32]. Furthermore some parents can perceive time pressure to start the treatment as soon as possible after the diagnosis and this can lead to a lack of time to discuss all the possibilities with the physician [38].

The potential risks arising from participation in a RCT are often not correctly recalled by parents. If asked after signing the consent form, and even if they recall some of the risks of the treatment itself, they often do not report any risks associated with the study design [14,39]. Also the assessment of risks of participation changes with the age of parents and the experience of being a research volunteer: older parents perceive the risks as lower than younger parents and previous participation in medical research results in a more positive perception of the risk/ benefit ratio $[33,40]$.

As concerns parents' perception of risks, it was found that parents also feared that medications developed for adults may harm children, especially if new medications with unknown adverse effects profiles were tested [15]. The level of perceived risk differs between parents having enough time to decide about participation and parents without sufficient time [41]. Parents who had little time to decide perceived fewer risks associated with participation in the clinical trial than parents who had had more time to make the decision.

Even after signing the consent form, parents frequently seem to misunderstand the concept of randomisation [42-44]. The randomization process should be explained more clearly: Parents need to be clearly informed that random assignment is one of the procedures that differentiates participating in the RCT from standard treatment $[18,35,44-46]$. The lack of understanding of randomization may result in a parent's disappointment $[32,43]$ that their child was assigned to the control group.

Parents of ethnic minorities and lower socioeconomic status have been found to be less likely to understand the characteristics of a RCT such as randomization [12-14, 47].

Also, understanding the freedom to withdraw seems somewhat difficult among parents of RCT participants. Many parents were not aware at the time of giving consent that they can refuse participation or withdraw from the study at any time without negative consequences for their child $[13,19,39]$. Several studies $[48,49]$ reported that between $45 \%$ and $80 \%$ of parents understood that they can withdraw their child from the ongoing study.

After some time, many parents may even forget that they have been approached for consent and that their child participated in a clinical trial $[44,50]$.

\subsection{Decision Making}

\subsubsection{Inclusion of Children in Decisions about Participation}

Including children in the process of consenting and deciding about participation in a clinical trial is a challenge. The level of child involvement in the process of decision making is variable and depends on many socio-cultural and legislative aspects [18]. Although child involvement is desirable, there are different views concerning the nature of this involvement as well as the age thresholds for allowing the child's involvement $[20,51]$. 
Most parents prefer to have the initial decision whether or not to consider their child's participation in a research project [52]. When deciding about their child's level of involvement in the decision making, most parents would take into account the age and developmental stage of their child [52]. Older children are significantly more likely to be included in the consent conference, than their younger counterparts [24] and they ask significantly more questions [53].

In consent conferences with the child present as compared to those when the child is absent, parents asked significantly fewer questions [53]. In the decision situation the majority of younger patients wanted some parental input, but they still thought that the final decision should be theirs $[18,24,51]$. The less risky the research is perceived to be and the more open the communication style is, the greater the likelihood is that decisions would be made jointly by parents and child [52].

Children with cancer have been reported to be less involved in the decision-making process than children with diabetes [18]. When a situation is life-threatening parents prefer to make the final decision on their own [42].

Adolescents play a special role in the decision-making process: because of their higher independence they are less willing to let their parents decide on their behalf [54].

\subsubsection{Relations and Communication}

Paediatric clinicians have a unique relationship with their patients and are expected to place the patients' best interests over any personal, professional or third-party interests. However, parents may be concerned about the possibility that doctors care more about the study than about the patients. Some parents may even fear that the clinician as researcher is more interested in his or her own career promotion than the patients' interests $[13,15]$.

The way physicians communicate might dominate the interchange that occurs during the informed consent. Considering their clinical and research-related responsibilities, physicians need to provide detailed and understandable information to parents and children $[12,18]$. Difficulties in communication between parents and physician are also caused by physicians' use of medical jargon, provoking misunderstanding [37].

Differences have been reported in parental need for the amount of information given during the informed consent process, with some parents claiming there was too much, not enough or just the right amount of information provided $[16,37,43,53]$. Still, the majority of parents reported that the discussion with the staff was very helpful when going through informed consent process [36]. In fact, personal discussion with the clinician appears to be the best way to secure good understanding the complex information [55].

Parents have been described to feel dependent on cli- nicians and to experience considerable unease in making decisions about trial participation $[34,41,56]$.

Parents' communications with physicians focus more extensively on the child's illness, treatment, risks or benefits than on the RCT with its risks or procedures such as randomization $[12,41,53]$.

It can be expected that active parental behaviour in the consent process would lead to an involvement of parents in the planning of the treatment. Physician's communication style has a substantial impact on the parental decision-making process [53], as has the socioeconomic status of the parents $[12,47]$.

\subsubsection{Emotional State and Willingness to Volunteer}

A life-threatening situation substantially limits parents' perception of the optional nature of enrolling their child into a RCT $[38,57,58]$.

Parents who are anxiously concerned about the health of their child might not recall being given information as much as adults who act on their own behalf [11,12,35]. They are also concerned about the health of their child and feel pressure to give consent [11]. In such a stressful situation, a notable group of parents state that they feel obliged to take part in the study or that they feel to have no choice in the interest of their child's health [59-61]. In contrast, in emergency situations parents fear that doing research would cause a delay starting the proper treatment $[15,57]$.

After receiving the diagnosis, parents go through a massive psychological stress reaction [37], including experiencing emotions such as fear, confusion, shock, grief and anxiety $[37,41]$. Some parents described the experience "It was unbelievable stress" [37] or "We were so shocked, we signed without knowing much" [48]. Parents reported feeling unable to absorb the information from the informed consent process because of an emotional shock they were experiencing after the recent diagnosis of their child [37,38,48,49]. Some parents reported that in this context they felt that they had no influence on the treatment decision, that they were not given a choice during the consent process [37], experienced lack of control over who was present during the decision about their child's treatment, were not feeling competent enough to understand complex information related to consent process and lacked support to help them to understand and deal with the situation [37]. Parents who only had a short time for decision and parents who had one day did not differ in emotions and decisions made [41].

\subsection{Participation}

\subsubsection{Children's Perspectives}

When asked about reasons for participating in a trial, 
children, particular those suffering from severe illnesses like cancer, often report motivations such as "To get help for my problem", "To find out what is bothering me” $[18,51,60,62]$. Other reasons for participation which were less frequent were: "To help other people with problems" [51,56,60], "My doctor told me to be in the study" [51,60], or "My parents told me to be in the study" [60].

Financial compensation or reimbursement also plays a role here. Some of the younger patients especially those with mild diseases expect this, mentioning "I will get money when I come here" as a reason for participating $[18,60]$. However, one study in children with asthma found that financial reasons are not an important reason for participating [63].

\subsubsection{Parent's Perspectives}

For the parents of ill children, reasons for participating include health-related benefits such as receiving treatment for the child and learning about the disease [33,40, 60,61,64-67]. Less frequent was dissatisfaction with prior treatment and financial reimbursement [60]. Other studies confirmed this, but stressed motives such as contribution to science and the benefit to other children [33, $55,59,60,64]$. These altruistic considerations are often invoked by clinicians; this might imply that altruistic motives are resulting from the consent discussion [68]. Parents might also feel a sense of obligation associated with the fact that their children were benefiting from previous clinical research [43].

Among perceived benefits were an offer of hope [41, 42], the belief that the RCT guarantees receiving the most advanced treatment available for their child $[37,42$, 43], the belief that participation in a RCT improves survival rates [43], the belief that participation in a RCT will result in a higher level of attention from medical staff $[37,43]$, as well as the possibility to meet others in the same position [42].

Also relevant were organisational reasons such as the existence of appointments which were made for the initial medical therapy so that participation won't take much effort or the location of the clinic $[42,51,56,61,62]$.

Among the risks perceived by parents were unknown side effects of the experimental treatment, being randomized into ineffective treatment and inconvenience of participation [42,57].

Parents who had already participated in studies were willing to take part in future studies [59]. The availability of the research results also plays an important role here. Parents declare that because of receiving research results they have acquired additional knowledge about the health state of their child [69]. Moreover, information about research results makes parents feel more as a partner than as a research subject in medical research $[70,71]$.

\subsubsection{Enrolment and Withdrawal}

The rate of consent is higher if the return of the information and the consent form is delivered personally instead of by mail. Follow-up techniques like phone calls after mailing out the consent forms might help secure the consent to participation $[33,72]$. It has been shown that adolescent participants prefer to be approached with youth-specific materials and strategies [60].

Reasons for refusing to participate included reservations about time and inconvenience as well as specific aspects such as fears regarding the randomization process and its outcome or the use of needles as a part of blood testing $[59,61,66]$. Parents tended to decline participation if they wanted a specific treatment for their child and were opposed to randomization. The parents who declined perceived experimental treatment as superior to the control group [59]. Parents have been reported to refuse participation because of the assumed stress for child or because they simply disliked the idea $[15,33,59]$.

Adolescents' reasons for declining participation included increased clinic visits, increased number treatment interventions [73], increased frequency of diagnostic procedures, transportation issues and the opposition to randomization [56,73].

Perceived health status is another reason for premature cessation of participation. In diseases which remain asymptomatic for a long time, the probability for an early attrition of participants increases [72,74]. The withdrawal rates will rise, however, if participants perceive an improvement of their health status [75]. Frequent reasons for premature withdrawal from a study are long delays to follow-up or family constraints [74,76]. Even if patients were reporting mild to moderate adverse effects while participating in a trial, this was not one of the main reasons for discontinuing participation [76,77].

\section{DISCUSSION}

The results of the literature reviewed indicate that the patient and parent comprehension of information provided to potential participants of clinical trials is often limited. This understanding might improve if researchers give the information to the participants in an open discussion. However, new ways to fulfil the special needs of young patients and their families in the situation of considering participation in a clinical trial are needed.

In order to ensure understanding, clinicians and researchers should be aware of the level of cognitive and reading comprehension of potential paediatric research participants and adjust their message in accordance [13, 14,27]. Consent forms and consent communication should be provided in all languages used in the study population [16], this idea is reflected in a recent EUrecommendation [7]. 
For the understanding of assent or consent in young patients, age-appropriate information is highly desirable and children's point of view should be taken into account. It is possible to set up focus groups consisting of children with a specific condition so that they can express their opinion about the content and the design of the assent or consent documents [22].

Sufficient parents' assessment of the risk/benefit ratio of participation is only possible by receiving the appropriate amount of information, provided in a clear formulation. As there are many differences concerning the amount of information made available to parents making the decision about participation, there is a need for several consent documents containing sufficient legal information, but differing in the amount of background information provided and being improved for better readability $[28,33,40]$.

The randomization process should be explained more explicitly: Parents need to be clearly informed that random assignment is one of the procedures that differentiates participating in the randomized clinical trial (and other trial designs) from standard treatment [18,35, 44-46]. Therefore it is necessary to indicate to parents when the clinician is discussing trial-related issues and when they are discussing standard treatment issues [35].

Since many parents find it difficult to recognise that their child participated in a clinical trial, more attention should be paid to the decision-making process and to empowering parents and young patients to make a distinct decision [50]. The simple assessing of the amount of consent information recalled by parents or participants is only one of several methods of assessing the level of understanding.

Strategies to promote question-asking are needed to include the young patient in the decision-making process [53]. Partnership-building establishes a supportive communicative context that encourages parental participation in the process of informed consent [12,32,35,53]. Training researchers or clinicians in terms of their communication skills before the consent conference is essential to ensure good mutual communication [11].

Beyond the quality of communication, more attention should be paid to the emotional state and stress families may experience in the situation of disclosure of a diagnosis, frequently associated with the consent conference. A continual dialogue needs to be established which gives young patients and their parents the opportunity to exchange information about the study as well as reports how they would be affected by participating in the trial [38]. Participants and their families experiencing the emotional impact of a diagnosis may need psychological support [37].

When asked about their motivations, children and parents often report personal benefits as a strong motive for participation. It is important to clarify that clinical trials differ in their extent of possible personal benefits for the participants [51]. Researchers have a social responsibility and awareness of the fact that young patients and their families are often not able to calculate the risks of participation or understand the conceptual framework of medical research including randomization [65]. Altruistic reasons for participation can only be evoked if researchers explain this aspect [68].

Moreover, an extended communication pattern providing patients and their families with study results (for example, in the form of a letter, or a telephone conversation) is a crucial part of empowering children and their parents in the field of medical research [70,71].

The inclusion of patients' and their parents' view about participating in clinical trials is relatively new subject in the literature. Flexibility in the search strategy enabled us to identify a broad spectrum of publications focussing on this topic of research. Nevertheless literature relevant to our subject might not have been identified, so that this review is a starting point for further research and discussion about inclusion of patients' point of view.

Children's needs in clinical trials differ according to age, diagnosis, severity of disease, earlier experiences with medical research, study design and the socioeconomic status of their family. It is important to acknowledge parents' and children's involvement in the decision process as a prerequisite for participation, and to view it from the perspective of a psychological process. Mere attention to legislation and regulations, although necessary to provide safety of the trial and to comply with good clinical practice guidelines, is not enough. Empirical research should address more specifically cognitions and behaviours of parents and patients in making decisions about participation. Past research about the participation of children in clinical trials focused mostly on the consent process, the decision making and the reasons for participation or declining. A broader approach is now needed to gather the complexity of this particular situation. That means that future research should examine needs, emotions, thoughts and fears of children and their families considering participation or participating already. Addressing available psychological knowledge might be helpful in understanding the needs of children and parents and, based on this, improving participation levels and enhancing the family's experience of the clinical trial itself.

\section{ACKNOWLEDGEMENTS}

The research leading to these results has received funding from the European Union's Seventh Framework Programme (FP7/2007-2013) under grant agreement n 201938.

The RESPECT study group: Chaplin $\mathrm{J}^{2}$, Chaplin $\mathrm{C}^{2}$, Pfeiffer- 
Mosesson $C^{2}$, Bullinger $M^{1}$, Wulf $F^{1}$, Mackensen $S^{1}$, Sanna $L^{3}$, Wool $\mathrm{PS}^{4}$, Giaquinto $\mathrm{C}^{4}$, Altavilla $\mathrm{A}^{5}$, Neubauer $\mathrm{D}^{6}$, Kodric $\mathrm{J}^{6}$, Crawley $\mathrm{FP}^{7}$, Manfredi $\mathrm{M}^{8}$ and Ceci $\mathrm{A}^{8}$.

${ }^{1}$ University Medical Center Hamburg-Eppendorf, Center for Psychosocial Medicine; ${ }^{2}$ Göteborg Pediatric Growth Research Center, The Sahlgrenska Academy at Göteborg University; ${ }^{3}$ European Patients Forum, Brussels; ${ }^{4}$ Dept of Paediatrics, L’Università degli Studi di Padova; ${ }^{5}$ Université de la Méditerranée (Aix-Marseille II); ${ }^{6}$ Department of Child, Adolescent \& Developmental Neurology, Univ. Children's Hospital, Ljubljana, Slovenia; ${ }^{7}$ Good Clinical Practice Alliance- Europe; ${ }^{8}$ Consorzio per le Valutazioni Biologiche e Farmaco-logiche (CVBF), Pavia.

The authors indicated no potential conflicts of interest.

\section{REFERENCES}

[1] Caldwell, P., Murphy, S., Butow, P. and Craig, J. (2004) Clinical trials in children. The Lancet, 364, 803-811. doi:10.1016/S0140-6736(04)16942-0

[2] Smyth, R. (2001) Research with children. British Medical Journal, 322, 1377-1378. doi:10.1136/bmj.322.7299.1377

[3] Smyth, R. and Weindling, A. (1999) Research in children: Ethical and scientific aspects. The Lancet, 354, SII21SII24. doi:10.1016/S0140-6736(99)90253-2

[4] Regulation (EC) No 1901/2006 of the European Parliament and of the Council of 12 December 2006 on medicinal products for paediatric use and amending Regulation (EEC) No 1768/92, Directive 2001/20/EC, Directive 2001/83/EC and Regulation (EC) No 726/2004.

http://eur-lex.europa.eu/LexUriServ/site/en/consleg/2006/ $\underline{\text { R/02006R1901-20070126-en.pdf }}$

[5] European Medicines Agency (2002) ICH Topic E 6 (R1) guideline for good clinical practice. http://www.emea.europa.eu/pdfs/human/ich/013595en.pd f

[6] Directive 2001/20/EC of the European Parliament and of the Council (2001) Approximation of the laws, regulations and administrative provisions of the Member States relating to the implementation of good clinical practice in the conduct of clinical trials on medicinal products for human use. Official Journal, 121, 34-44.

[7] The ad hoc group for the development of implementing guidelines for Directive 2001/20/EC relating to good clinical practice in the conduct of clinical trials on medicinal products for human use (2008) Ethical considerations for clinical trials on medicinal products conducted with the paediatric population.

http://ec.europa.eu/enterprise/pharmaceuticals/eudralex/v ol-10/ethical considerations.pdf

[8] Pinxten, W., Nys, H. and Dierickx, K. (2010) Frontline ethical issues in pediatric clinical research: Ethical and regulatory aspects of seven current bottlenecks in pediatric clinical research. European Journal of Pediatrics, 169, 1541-1548. doi:10.1007/s00431-010-1268-6

[9] Altavilla, A., Giaquinto, C. and Ceci, A. (2008) European survey on ethical and legal framework of clinical trials in paediatrics: Results and perspectives. Journal International de Bioéthique, 19, 17-48.

[10] Frosch, D.L. and Kaplan, R.M. (1999) Shared decision making in clinical medicine: Past research and future directions. American Journal of Preventive Medicine, 17, 285-294. doi:10.1016/S0749-3797(99)00097-5

[11] Allmark, P. and Mason, S. (2006) Improving the quality of consent to randomised controlled trials by using continuous consent and clinician training in the consent process. Journal of Medical Ethics, 32, 439-443. doi:10.1136/jme.2005.013722

[12] Drotar, D., Miller, V., Willard, V., Anthony, K. and Kodish, E. (2004) Correlates of parental participation during informed consent for randomized clinical trials in the treatment of childhood leukemia. Ethics \& Behavior, 14, 1-15. doi:10.1207/s15327019eb1401_1

[13] Hazen, R., Drotar, D. and Kodish, E. (2007) The role of the consent document in informed consent for pediatric leukemia trials. Contemporary Clinical Trials, 28, 401408. doi:10.1016/j.cct.2006.10.011

[14] Kodish, E., Eder, M., Noll, R., Ruccione, K., Lange, B., Angiolillo, A., Pentz, R., Zyzanski, S., Siminoff, L. and Drotar, D. (2004) Communication of randomization in childhood leukemia trials. Journal of the American Medical Association, 291, 470-475. doi:10.1001/jama.291.4.470

[15] Morris, M., Besner, D., Vazquez, H., Nelson, R. and Fischbach, R. (2007) Parental opinions about clinical research. The Journal of Pediatrics, 151, 532-537.

[16] Eder, M., Yamokoski, A., Wittmann, P. and Kodish, E. (2007) Improving informed consent: Suggestions from parents of children with leukemia. Pediatrics, 119, 849859. doi:10.1542/peds.2006-2208

[17] Tait, A., Voepel-Lewis, T. and Malviya, S. (2003) Do they understand? (part II): Assent of children participating in clinical anesthesia and surgery research. Anesthesiology, 98, 609-614. doi:10.1097/00000542-200303000-00006

[18] Broome, M., Richards, D. and Hall, J. (2001) Children in research: The experience of ill children and adolescents. Journal of Family Nursing, 7, 32-49. doi:10.1097/00000542-200303000-00006

[19] John, T., Hope, T., Savulescu, J., Stein, A. and Pollard, A.J. (2008) Children's consent and paediatric research: Is it appropriate for healthy children to be the decisionmakers in clinical research? Archives of Disease in Childhood, 93, 379-383. doi:10.1136/adc.2007.118299

[20] Ondrusek, N., Abramovitch, R., Pencharz, P. and Koren, G. (1998) Empirical examination of the ability of children to consent to clinical research. Journal of Medical Ethics, 24, 158-165. doi:10.1136/jme.24.3.158

[21] Tait, A., Voepel-Lewis, T. and Malviya, S. (2007) Presenting research information to children: A tale of two methods. Anesthesia \& Analgesia, 105, 358-364. doi:10.1213/01.ane.0000270326.44507.11

[22] Ford, K., Sankey, J. and Crisp, J. (2007) Development of children's assent documents using a child-centred approach. Journal of Child Health Care, 11, 19-28. 


\section{doi:10.1177/1367493507073058}

[23] Chappuy, H., Doz, F., Blanche, S., Gentet, J. and Treluyer, J. (2007) Children's views on their involvement in clinical research. Pediatric Blood \& Cancer, 50, 1043-1046. doi:10.1002/pbc.21359

[24] Unguru, Y., Sill, A. and Kamani, N. (2010) The experiences of children enrolled in pediatric oncology research: Implications for assent. Pediatrics, 125, e876-e883. doi:10.1542/peds.2008-3429

[25] Blake, D., Lemay, C., Kearney, M. and Mazor, K. (2010) Adolescent perspectives on informed assent for an HIV vaccine trial. Journal of Adolescent Health, 46, S28. doi:10.1016/j.jadohealth.2009.11.066

[26] Simon, C., Zyzanski, S., Eder, M., Raiz, P., Kodish, E. and Siminoff, L. (2003) Groups potentially at risk for making poorly informed decisions about entry into clinical trials for childhood cancer. Journal of Clinical Oncology, 21, 2173-2178. doi:10.1200/JCO.2003.03.003

[27] Campbell, F. (2004) The effect of format modifications and reading comprehension on recall of informed consent information by low-income parents: A comparison of print, video, and computer-based presentations. Patient Education and Counseling, 53, 205-216. doi:10.1016/S0738-3991(03)00162-9

[28] Tait, A., Voepel-Lewis, T., Malviya, S. and Philipson, S. (2005) Improving the readability and processability of a pediatric informed consent document: Effects on parents' understanding. Archives of Pediatrics \& Adolescent Medicine, 159, 347-352. doi:10.1001/archpedi.159.4.347

[29] Hazen, R., Eder, M., Drotar, D., Zyzanski, S., Reynolds, A., Reynolds, C., Kodish, E. and Noll, R. (2010) A feasibility trial of a video intervention to improve informed consent for parents of children with leukemia. Pediatric Blood \& Cancer, 55, 113-118.

[30] Angiolillo, A.L., Simon, C., Kodish, E., Lange, B., Noll, R.B., Ruccione, K. and Matloub, Y. (2004) Staged informed consent for a randomized clinical trial in childhood leukemia: Impact on the consent process. Pediatric Blood \& Cancer, 42, 433-437. doi:10.1002/pbc.20010

[31] Freer, Y., McIntosh, N., Teunisse, S., Anand, K. and Boyle, E. (2009) More information, less understanding: A randomized study on consent issues in neonatal research. Pediatrics, 123, 1301-1305. doi:10.1542/peds.2007-3860

[32] Massimo, L. and Wiley, T.J. (2005) Randomization, informed consent and physicians' communication skills in pediatric oncology: A delicate balance. Bulletin du Cancer, 92, E67-E69.

[33] Chantler, T., Lees, A., Moxon, E., Mant, D., Pollard, A. and Fiztpatrick, R. (2007) The role familiarity with science and medicine plays in parents' decision making about enrolling a child in vaccine research. Qualitative Health Research, 17, 311-322. doi:10.1177/1049732306298561

[34] Singhal, N., Oberle, K., Burgess, E. and Huber-Okrainec, J. (2002) Parents' perceptions of research with newborns. Journal of Perinatology, 22, 57-63. doi:10.1038/sj.jp.7210608

[35] Simon, C., Siminoff, L., Kodish, E. and Burant, C. (2004)
Comparison of the informed consent process for randomized clinical trials in pediatric and adult oncology. Journal of Clinical Oncology, 22, 2708-2717. doi:10.1200/JCO.2004.10.034

[36] Kodish, E., Pentz, R., Noll, R., Ruccione, K., Buckley, J. and Lange, B. (1998) Informed consent in the children's cancer group. Cancer, 82, 2467-2481. doi:10.1002/(SICI)1097-0142(19980615)82:12\%3C2467: :AID-CNCR22\%3E3.0.CO;2-M

[37] Levi, R., Marsick, R., Drotar, D. and Kodish, E. (2000) Diagnosis, disclosure, and informed consent: Learning from parents of children with cancer. Journal of Pediatric Hematology/Oncology, 22, 3-12. doi:10.1097/00043426-200001000-00002

[38] Stevens, P. and Pletsch, P. (2002) Ethical issues of informed consent: Mothers' experiences enrolling their children in bone marrow transplantation research. Cancer Nursing, 25, 81-87. doi:10.1097/00002820-200204000-00001

[39] Chappuy, H., Baruchel, A., Leverger, G., Oudot, C., Brethon, B., Haouy, S., Auvrignon, A., Davous, D., Doz, F. and Tréluyer, J.M. (2010) Parental comprehension and satisfaction in informed consent in paediatric clinical trials: A prospective study on childhood leukaemia. Archives of Disease in Childhood, 95, 800-804. doi:10.1136/adc.2009.180695

[40] Tait, A., Voepel-Lewis, T. and Malviya, S. (2004) Factors that influence parents' assessments of the risks and benefits of research involving their children. Pediatrics, 113, 727-732. doi:10.1542/peds.113.4.727

[41] Snowdon, C., Elbourne, D. and Garcia, J. (2006) "It was a snap decision": Parental and professional perspectives on the speed of decisions about participation in perinatal randomised controlled trials. Social Science \& Medicine, 62, 2279-2290. doi:10.1016/j.socscimed.2005.10.008

[42] Caldwell, P., Butow, P. and Craig, J. (2003) Parents' attitudes to children's participation in randomized controlled trials. The Journal of Pediatrics, 142, 554-559. doi:10.1067/mpd.2003.192

[43] Eiser, C., Davies, H., Jenney, M. and Glaser, A. (2005) Mothers' attitudes to the randomized controlled trial (RCT): The case of acute lymphoblastic leukaemia (ALL) in children. Child: Care, Health and Development, 31, 517-523. doi:10.1111/j.1365-2214.2005.00538.x

[44] Kupst, M., Patenaude, A., Walco, G. and Sterling, C. (2003) Clinical trials in pediatric cancer: Parental perspectives on informed consent. Journal of Pediatric Hematology/Oncology, 25, 787-790. doi:10.1097/00043426-200310000-00009

[45] Greenley, R., Drotar, D., Zyzanski, S. and Kodish, E. (2006) Stability of parental understanding of random assignment in childhood leukemia trials: An empirical examination of informed consent. Journal of Clinical Oncology, 24, 891-897. doi:10.1200/JCO.2005.02.8100

[46] Wiley, F.M., Ruccione, K., Moore, I., McGuire-Cullen, P., Fergusson, J., Waskerwitz, M., Perin, G., Ge, J. and Sather, H. (1999) Parents' perceptions of randomization in pediatric clinical trials. Cancer Practice, 7, 248-256. doi:10.1046/j.1523-5394.1999.75010.x 
[47] Miller, V., Drotar, D., Burant, C. and Kodish, E. (2005) Clinician-parent communication during informed consent for pediatric leukemia trials. Journal of Pediatric Psychology, 30, 219-229. doi:10.1093/jpepsy/jsi032

[48] Burgess, E., Singhal, N., Amin, H., McMillan, D., Devrome, H. and Fenton, A. (2003) Consent for clinical research in the neonatal intensive care unit: A retrospective survey and a prospective study. Archives of Disease in Childhood Fetal and Neonatal Edition, 88, F280-F286. doi:10.1136/fn.88.4.F280

[49] Mason, S. and Allmark, P. (2000) Obtaining informed consent to neonatal randomised controlled trials: Interviews with parents and clinicians in the Euricon study. The Lancet, 356, 2045-2051. doi:10.1016/S0140-6736(00)03401-2

[50] Stenson, B.J., Becher, J.C. and McIntosh, N. (2004) Neonatal research: The parental perspective. Archives of Disease in Childhood Fetal and Neonatal Edition, 89, F321F324. doi:10.1136/adc.2002.021931

[51] Varma, S., Jenkins, T. and Wendler, D. (2008) How do children and parents make decisions about pediatric clinical research? Journal of Pediatric Hematology, 30, 823-828. doi:10.1097/MPH.0b013e318180bc0d

[52] Geller, G., Tambor, E., Bernhardt, B., Fraser, G. and Wissow, L. (2003) Informed consent for enrolling minors in genetic susceptibility research: A qualitative study of at-risk children's and parents' views about children's role in decision-making. Journal of Adolescent Health, 32, 260-271. doi:10.1016/S1054-139X(02)00459-7

[53] Olechnowicz, J., Eder, M., Simon, C., Zyzanski, S. and Kodish, E. (2002) Assent observed: Children's involvement in leukemia treatment and research discussions. $\mathrm{Pe}$ diatrics, 109, 806-814. doi:10.1542/peds.109.5.806

[54] Brody, J., Scherer, D., Annett, R., Turner, C. and Dalen, J. (2006) Family and physician influence on asthma research-participation decisions for adolescents: The effects of adolescent gender and research risk. Pediatrics, 118, e356-e362. doi:10.1542/peds.2005-2589

[55] Hayman, R., Taylor, B., Peart, N., Galland, B. and Sayers, R. (2001) Participation in research: Informed consent, motivation and influence. Journal of Paediatrics and Child Health, 37, 51-54. doi:10.1046/j.1440-1754.2001.00612.x

[56] Dolan, L., Sabesan, V., Weinstein, S. and Spratt, K. (2008) Preference assessment of recruitment into a randomized trial for adolescent idiopathic scoliosis. The Journal of Bone and Joint Surgery (American), 90, 2594-2605. doi:10.2106/JBJS.G.01460

[57] Morris, M., Nadkarni, V., Ward, F. and Nelson, R. (2004) Exception from informed consent for pediatric resuscitation research: Community consultation for a trial of brain cooling after in-hospital cardiac arrest. Pediatrics, 114, 776-781. doi:10.1542/peds.2004-0482

[58] McGrath, P. (2002) Beginning treatment for childhood acute lymphoblastic leukemia: Insights from the parents' perspective. Oncology Nursing Forum, 29, 988-996. doi:10.1188/02.ONF.988-996

[59] Sammons, H., Atkinson, M., Choonara, I. and Stephenson,
T. (2007) What motivates British parents to consent for research? A questionnaire study. BMC Pediatrics, 7, 12. doi:10.1186/1471-2431-7-12

[60] Wagner, K., Martinez, M. and Joiner, T. (2006) Youths' and their parents' attitudes and experiences about participation in psychopharmacology treatment research. Journal of Child and Adolescent Psychopharmacology, 16, 298-307. doi:10.1089/cap.2006.16.298

[61] Stuijvenberg, M., Suur, M., Vos, S., Tjiang, G., Steyerberg, E., Derksen-Lubsen, G. and Moll, H. (1998) Informed consent, parental awareness, and reasons for participating in a randomised controlled study. Archives of Disease in Childhood, 79, 120-125. doi:10.1136/adc.79.2.120

[62] Brody, J., Annett, R., Scherer, D., Perryman, M. and Cofrin, K. (2005) Comparisons of adolescent and parent willingness to participate in minimal and above minimal risk pediatric asthma research protocols. The Journal of adolescent health, 37, 229-235. doi:10.1016/j.jadohealth.2004.09.026

[63] Scherer, D., Brody, J., Annett, R., Hetter, J., Roberts, L. and Cofrin, K. (2005) Financial compensation to adolescents for participation in biomedical research: Adolescent and parent perspectives in seven studies. The Journal of Pediatrics, 146, 552-558. doi:10.1016/j.jpeds.2004.12.024

[64] Hoehn, K., Wernovsky, G., Rychik, J., Gaynor, J., Spray, T., Feudtner, C. and Nelson, R. (2005) What factors are important to parents making decisions about neonatal research? Archives of Disease in Childhood Fetal and Neonatal Edition, 90, F267-F269. doi:10.1136/adc.2004.065078

[65] Rothmier, J.D., Lasley, M.V. and Shapiro, G.G. (2003) Factors influencing parental consent in pediatric clinical research. Pediatrics, 111, 1037-1041. doi:10.1542/peds.111.5.1037

[66] Pletsch, P.K. and Stevens, P.E. (2001) Inclusion of children in clinical research: Lessons learned from mothers of diabetic children. Clinical Nursing Research, 10, 140162. doi:10.1177/10547730122158842

[67] Zupancic, J., Gillie, P., Streiner, D., Watts, J. and Schmidt, B. (1997) Determinants of parental authorization for involvement of newborn infants in clinical trials. Pediatrics, 99, E6. doi:10.1542/peds.99.1.e6

[68] Simon, C., Eder, M., Kodish, E. and Siminoff, L. (2006) Altruistic discourse in the informed consent process for childhood cancer clinical trials. The American Journal of Bioethics, 6, 40-47. doi:10.1080/15265160600862395

[69] Fernandez, C., Gao, J., Strahlendorf, C., Moghrabi, A., Pentz, R., Barfield, R., Baker, J., Santor, D., Weijer, C. and Kodish, E. (2009) Providing research results to participants: Attitudes and needs of adolescents and parents of children with cancer. Journal of Clinical Oncology, 27, 878-883. doi:10.1200/JCO.2008.18.5223

[70] Fernandez, C., Santor, D., Weijer, C., Strahlendorf, C., Moghrabi, A., Pentz, R., Gao, J. and Kodish, E. (2007) The return of research results to participants: Pilot questionnaire of adolescents and parents of children with cancer. Pediatric Blood \& Cancer, 48, 441-446. 


\section{doi:10.1002/pbc.20766}

[71] Snowdon, C., Garcia, J. and Elbourne, D. (1998) Reactions of participants to the results of a randomised controlled trial: Exploratory study. British Medical Journal, 317, 21-26.

[72] Gómez-Marín, O., Prineas, R. and Sinaiko, A. (1991) The sodium-potassium blood pressure trial in children: Design, recruitment, and randomization: The children and adolescent blood pressure program. Controlled Clinical Trials, 12, 408-423. doi:10.1016/0197-2456(91)90020-M

[73] Tercyak, K., Johnson, S., Kirkpatrick, K. and Silverstein, J. (1998) Offering a randomized trial of intensive therapy for IDDM to adolescents. Reasons for refusal, patient characteristics, and recruiter effects. Diabetes Care, 21, 213-215. doi:10.2337/diacare.21.2.213

[74] Crom, D., Tyc, V., Rai, S., Deng, X., Hudson, M., Booth, A., Rodrigues, L., Zhang, L., Mccammon, E. and Kaste, S. (2006) Retention of survivors of acute lymphoblastic leukemia in a longitudinal study of bone mineral density. Journal of Child Health Care, 10, 337-350. doi:10.1177/1367493506067886

[75] Sederberg-Olsen, J., Sederberg-Olsen, N., Thomsen, J. and Balle, V. (1998) Problems in recruiting patients to controlled trials on children with secretory otitis media: A demographic comparison of excluded versus included patients. International Journal of Pediatric Otorhinolaryngology, 43, 229-233. doi:10.1016/S0165-5876(98)00004-4

[76] Reitamo, S., Rustin, M., Harper, J., Kalimo, K., Rubins, A., Cambazard, F., Brenninkmeijer, E., Smith, C., BerthJones, J., Ruzicka, T., Sharpe, G. and Taieb, A. (2008) A 4-year follow-up study of atopic dermatitis therapy with $0.1 \%$ tacrolimus ointment in children and adult patients. British Journal of Dermatology, 159, 942-951. doi:10.1111/j.1365-2133.2008.08747.x

[77] Ruperto, N., Lovell, D., Cuttica, R., Woo, P., Meiorin, S., Wouters, C., Silverman, E., Balogh, Z., Henrickson, M., Davidson, J., Foeldvari, I., Imundo, L., Simonini, G., Oppermann, J., Xu, S., Shen, Y., Visvanathan, S., Fasanmade, A., Mendelsohn, A., Martini, A. and Giannini, E. (2010) Long-term efficacy and safety of infliximab plus methotrexate for the treatment of polyarticular-course juvenile rheumatoid arthritis: Findings from an open-label treatment extension. Annals of the Rheumatic Diseases, 69, 718-722. doi:10.1136/ard.2009.100354 


\section{Appendix}

Table A1. List of empirical studies.

\begin{tabular}{|c|c|c|c|c|c|c|c|c|}
\hline & & & & & & \multicolumn{3}{|c|}{ Cluster } \\
\hline Article & Study design & Data collection & $\mathbf{n}$ & $\begin{array}{l}\text { Ages } \\
\text { in parentheses: } \\
\text { age of children }\end{array}$ & Objectives & 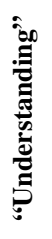 & 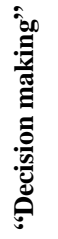 & 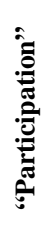 \\
\hline $\begin{array}{c}\text { Allmark \& } \\
\text { Mason } 2006[11]\end{array}$ & $\operatorname{CSDS}(\mathrm{RCT})^{1}$ & $\begin{array}{l}\text { semistructured } \\
\text { interview }\end{array}$ & 27 & $\begin{array}{l}\text { Parents } \\
\text { (Neonates) }\end{array}$ & $\begin{array}{l}\text { assess whether continuous consent, a } \\
\text { process in which information is given } \\
\text { to research participants at different } \\
\text { stages in a trial, and clinician training } \\
\text { in that process were effective when } \\
\text { used by clinicians while gaining } \\
\text { consent }\end{array}$ & $\mathrm{x}$ & $\mathrm{x}$ & \\
\hline $\begin{array}{l}\text { Angiolillo } \\
\text { et al. } 2004 \text { [30] }\end{array}$ & CSDS (RCT) & questionnaire & 140 & Parents & $\begin{array}{l}\text { examine the utilization of a staged } \\
\text { approach to the consent process }\end{array}$ & $\mathrm{x}$ & & \\
\hline $\begin{array}{l}\text { Blake } \\
\text { et al. } 2010 \text { [25] }\end{array}$ & FGS & $\begin{array}{l}\text { semistructured } \\
\text { interview }\end{array}$ & 8 & 15 to 17 & $\begin{array}{l}\text { identify misunderstandings and mis- } \\
\text { conceptions that could prevent ado- } \\
\text { lescents from being able to provide } \\
\text { truly informed assent }\end{array}$ & $\mathrm{x}$ & & \\
\hline $\begin{array}{l}\text { Brody } \\
\text { et al. } 2006 \text { [54] }\end{array}$ & CSDS & $\begin{array}{l}\text { semistructured } \\
\text { interview }\end{array}$ & 36 & $\begin{array}{l}11 \text { to } 17 \\
M=13 \& \\
\text { parents }\end{array}$ & $\begin{array}{l}\text { examine parent and adolescent per- } \\
\text { ceptions of decision-making author- } \\
\text { ity and sources of influence on ado- } \\
\text { lescent research participation deci- } \\
\text { sions, and determine whether percep- } \\
\text { tions of influence differ based on } \\
\text { adolescent gender and level of re- } \\
\text { search risk }\end{array}$ & & $\mathrm{x}$ & $\mathrm{x}$ \\
\hline $\begin{array}{l}\text { Brody } \\
\text { et al. } 2005 \text { [62] }\end{array}$ & CSDS & $\begin{array}{l}\text { semistructured } \\
\text { interview }\end{array}$ & 36 & $\begin{array}{l}11 \text { to } 17, \\
M=13 \\
\& \text { parents }\end{array}$ & $\begin{array}{l}\text { compare parent and adolescent will- } \\
\text { ingness to participate in minimal and } \\
\text { above minimal risk pediatric asthma } \\
\text { research protocols }\end{array}$ & & $\mathrm{x}$ & $\mathrm{x}$ \\
\hline $\begin{array}{l}\text { Broome } \\
\text { et al. } 2001 \text { [18] }\end{array}$ & CSDS & $\begin{array}{l}\text { semistructured } \\
\text { interview }\end{array}$ & 34 & 8 to 22 & $\begin{array}{l}\text { examine (a) understanding about } \\
\text { research and (b) involvement in the } \\
\text { decision to participate in the clinical } \\
\text { trial }\end{array}$ & $x$ & $\mathrm{x}$ & $\mathrm{x}$ \\
\hline $\begin{array}{l}\text { Burgess } \\
\text { et al. } 2003[48]\end{array}$ & $\begin{array}{l}\text { retrospective } \\
\text { \& prospective } \\
\text { survey (RCT) }\end{array}$ & questionnaire & 83 & $\begin{array}{l}\text { Parents } \\
\text { (neonates) }\end{array}$ & $\begin{array}{l}\text { understand parental perceptions of } \\
\text { the process of recruitment and en- } \\
\text { rolment for research in the neonatal } \\
\text { intensive care unit }\end{array}$ & $\mathrm{x}$ & $\mathrm{x}$ & \\
\hline $\begin{array}{l}\text { Caldwell } \\
\text { et al. } 2003 \text { [42] }\end{array}$ & CSDS & focus groups & 33 & Parents & $\begin{array}{l}\text { explore parents' attitudes to chil- } \\
\text { dren’s participation in randomized } \\
\text { controlled trials }\end{array}$ & $\mathrm{x}$ & $\mathrm{x}$ & $\mathrm{x}$ \\
\hline $\begin{array}{l}\text { Campbell } \\
2004[27]\end{array}$ & RT & $\begin{array}{l}\text { quantitative test } \\
\text { \& qualitative recall }\end{array}$ & 233 & Parents & $\begin{array}{l}\text { comparing the amount of knowledge } \\
\text { orally recalled from four different } \\
\text { presentations of the same consent } \\
\text { information }\end{array}$ & $\mathrm{x}$ & & \\
\hline $\begin{array}{l}\text { Chantler } \\
\text { et al. } 2007 \text { [33] }\end{array}$ & CSDS (RCT) & $\begin{array}{l}\text { semistructured } \\
\text { interview }\end{array}$ & 34 & $\begin{array}{l}\text { Parents } \\
\text { (1 to } 3.5)\end{array}$ & $\begin{array}{l}\text { examine parental perception of clini- } \\
\text { cal research, particularly in emer- } \\
\text { gency settings }\end{array}$ & $\mathrm{x}$ & & $\mathrm{x}$ \\
\hline $\begin{array}{l}\text { Chappuy } \\
\text { et al. } 2010 \text { [39] }\end{array}$ & LS (RCT) & $\begin{array}{l}\text { semistructured } \\
\text { interview }\end{array}$ & 43 & $\begin{array}{l}\text { Parents } \\
(1.6 \text { to } 9.8 \\
\mathrm{M}=3.7)\end{array}$ & $\begin{array}{l}\text { evaluate the extent to which parents } \\
\text { are satisfied with and understand the } \\
\text { information they } \\
\text { are given when their consent is } \\
\text { sought for their child to participate in } \\
\text { a phase III randomised clinical trial } \\
\text { and the reasons for their decision }\end{array}$ & $\mathrm{x}$ & & \\
\hline
\end{tabular}




\section{Continued}

\begin{tabular}{|c|c|c|c|c|c|c|c|c|}
\hline $\begin{array}{c}\text { Chappuy } \\
\text { et al. } 2007 \text { [23] }\end{array}$ & CSDS & $\begin{array}{l}\text { semistructured } \\
\text { interview }\end{array}$ & 29 & 8.5 to 18 & $\begin{array}{l}\text { examine the level of children's } \\
\text { understanding of informed consent } \\
\text { in clinical trials and factors that } \\
\text { may influence these processes }\end{array}$ & $\mathrm{x}$ & & \\
\hline $\begin{array}{c}\text { Crom } \\
\text { et al. } 2006 \text { [74] }\end{array}$ & RCT & medical screening & 158 (133) & $\begin{array}{c}1 \text { to } 17 \\
(\mathrm{M}=5.2)\end{array}$ & $\begin{array}{l}\text { examine the variables associated } \\
\text { with dropout of survivors of acute } \\
\text { lymphoblastic leukemia in a trial }\end{array}$ & & & $\mathrm{x}$ \\
\hline $\begin{array}{c}\text { Dolan et al. } 2008 \\
\text { [56] }\end{array}$ & CSDS & $\begin{array}{c}\text { web-based } \\
\text { questionnaire }\end{array}$ & 173 & $\begin{array}{l}10 \text { to } 15 \\
\& \text { parents }\end{array}$ & $\begin{array}{l}\text { estimated the strength of three } \\
\text { common limitations (underenroll- } \\
\text { ment, selective nrol ent, and } \\
\text { nonadherence to protocol) in a } \\
\text { proposed study of adolescent idio- } \\
\text { pathic scoliosis }\end{array}$ & & $\mathrm{x}$ & $\mathrm{x}$ \\
\hline $\begin{array}{c}\text { Drotar } \\
\text { et al. } 2004 \text { [12] }\end{array}$ & CSS (RCT) & $\begin{array}{l}\text { qualitative } \\
\text { observation \& } \\
\text { transcripts }\end{array}$ & 140 & $\begin{array}{l}\text { Parents } \\
\text { (child's age } \\
\mathrm{M}=7.0 \text { ) }\end{array}$ & $\begin{array}{l}\text { examine the relationship of physi- } \\
\text { cian communication to parent } \\
\text { participation in informed consent } \\
\text { conference }\end{array}$ & $\mathrm{x}$ & $\mathrm{x}$ & \\
\hline $\begin{array}{c}\text { Eder } \\
\text { et al. } 2007 \text { [16] }\end{array}$ & CSS (RCT) & $\begin{array}{l}\text { qualitative observation, } \\
\text { transcripts, interviews } \\
\text { \& focus groups }\end{array}$ & 140 & $\begin{array}{l}\text { Parents } \\
(1 \text { to } 18 \\
\mathrm{M}=7.0)\end{array}$ & $\begin{array}{l}\text { report suggestions for improving } \\
\text { the informed consent process from } \\
\text { the perspective of parents }\end{array}$ & $\mathrm{x}$ & $\mathrm{x}$ & \\
\hline $\begin{array}{c}\text { Eiser } \\
\text { et al. } 2005 \text { [43] }\end{array}$ & LS (RCT) & $\begin{array}{l}\text { semistructured } \\
\text { interview }\end{array}$ & 50 & $\begin{array}{l}\text { Parents } \\
(4 \text { to } 16 \text {, } \\
M=7.4)\end{array}$ & $\begin{array}{l}\text { describe the views of mothers of } \\
\text { children newly diagnosed with } \\
\text { ALL regarding consent to random- } \\
\text { ized controlled trials }\end{array}$ & $\mathrm{x}$ & $\mathrm{X}$ & $\mathrm{x}$ \\
\hline $\begin{array}{c}\text { Fernandez } \\
\text { et al. } 2009 \text { [69] }\end{array}$ & CSDS & questionnaire & 495 & $\begin{array}{l}\text { Parents ( } 0 \text { to } \\
\text { 19, Med = 5) } \\
\text { \& adolescents }\end{array}$ & $\begin{array}{l}\text { define an appropriate process for } \\
\text { providing research results to par- } \\
\text { ticipants }\end{array}$ & & & $\mathrm{x}$ \\
\hline $\begin{array}{c}\text { Fernandez } \\
\text { et al. } 2007 \text { [70] }\end{array}$ & CSDS & questionnaire & $10 \& 30$ & $\begin{array}{l}\text { Adolescents } \\
\text { \& parents }\end{array}$ & $\begin{array}{l}\text { examine the needs and attitudes of } \\
\text { parents of children with cancer and } \\
\text { of adolescents with cancer to the } \\
\text { return of research results }\end{array}$ & & & $\mathrm{x}$ \\
\hline $\begin{array}{c}\text { Ford } \\
\text { et al. } 2007 \text { [22] }\end{array}$ & FGS & focus group & 12 & 6 to 12 & $\begin{array}{l}\text { include children in developing a } \\
\text { research information sheet and } \\
\text { assent form for use in future re- } \\
\text { search into children's understand- } \\
\text { ings of their surgery and hospital } \\
\text { experiences }\end{array}$ & $\mathrm{x}$ & & \\
\hline $\begin{array}{c}\text { Freer } \\
\text { et al. } 2009 \text { [31] }\end{array}$ & RCT & questionnaire & 41 & $\begin{array}{c}\text { Parents } \\
\text { (neonates) }\end{array}$ & $\begin{array}{l}\text { explore the impact of various in- } \\
\text { formation-sharing approaches on } \\
\text { parents' understanding of a re- } \\
\text { search study and the validity of } \\
\text { their consent }\end{array}$ & $\mathrm{x}$ & & \\
\hline $\begin{array}{c}\text { Geller } \\
\text { et al. } 2003 \text { [52] }\end{array}$ & CSDS & interview & 37 & $\begin{array}{l}\text { Parents \& } \\
\text { children } \\
\text { (10 to } 17)\end{array}$ & $\begin{array}{l}\text { understand the process by which } \\
\text { families at increased risk of disease } \\
\text { would decide in order to nrol } \\
\text { their children in genetic suscepti- } \\
\text { bility research }\end{array}$ & & $\mathrm{x}$ & \\
\hline $\begin{array}{l}\text { Gómez-Marín } \\
\text { et al. 1991 [72] }\end{array}$ & RCT & medical screening & 243 & 10 to 16 & $\begin{array}{l}\text { test the hypotheses that a reduction } \\
\text { in dietary sodium and/or an in- } \\
\text { crease in potassium intake will } \\
\text { decrease the rate of rise in blood } \\
\text { pressure during normal maturation } \\
\text { in children and adolescents with } \\
\text { high normal blood pressure }\end{array}$ & & & $\mathrm{x}$ \\
\hline $\begin{array}{c}\text { Greenley } \\
\text { et al. } 2006 \text { [45] }\end{array}$ & LS & interview & 84 & $\begin{array}{l}\text { Parents } \\
(1 \text { to } 18, \\
M=7.0)\end{array}$ & $\begin{array}{l}\text { examine stability versus change in } \\
\text { parental understanding of random } \\
\text { assignment in randomized clinical } \\
\text { trials (RCTs) for pediatric leukemia } \\
\text { and to identify factors associated } \\
\text { with changes in understanding }\end{array}$ & $\mathrm{x}$ & & \\
\hline
\end{tabular}




\section{Continued}

\begin{tabular}{|c|c|c|c|c|c|c|c|c|}
\hline $\begin{array}{l}\text { Hayman } \\
\text { et al. } 2001 \text { [55] }\end{array}$ & CSDS (CT) & $\begin{array}{l}\text { mixed quantitative/ } \\
\text { qualitative } \\
\text { questionnaire }\end{array}$ & 197 & $\begin{array}{l}\text { Parents } \\
\text { (babies) }\end{array}$ & $\begin{array}{l}\text { investigate the process and quality } \\
\text { of informed consent, motivation } \\
\text { and influence in parents who were } \\
\text { invited to enrol their baby in a } \\
\text { research project }\end{array}$ & & $\mathrm{x}$ & $\mathrm{x}$ \\
\hline $\begin{array}{c}\text { Hazen } \\
\text { et al. } 2010 \text { [29] }\end{array}$ & CSS & $\begin{array}{l}\text { Interview \& } \\
\text { observation }\end{array}$ & 12 & $\begin{array}{l}\text { Parents } \\
(\mathrm{M}=5.8)\end{array}$ & $\begin{array}{l}\text { assess the feasibility of and paren- } \\
\text { tal satisfaction with a video inter- } \\
\text { vention to improve informed con- } \\
\text { sent for pediatric leukemia RCTs } \\
\text { and to compare parental question } \\
\text { asking during informed consent } \\
\text { conferences (ICCs) for parents in } \\
\text { the current study with historical } \\
\text { control data }\end{array}$ & $\mathrm{x}$ & & \\
\hline $\begin{array}{l}\text { Hazen } \\
\text { et al. } 2007 \text { [13] }\end{array}$ & LS (RCT) & interview & 140 & $\begin{array}{l}\text { Parents } \\
(1 \text { to } 18 \\
\mathrm{M}=7.0)\end{array}$ & $\begin{array}{l}\text { examine both the use of the consent } \\
\text { document during the informed } \\
\text { consent process for pediatric leu- } \\
\text { kemia clinical trials, as well as } \\
\text { relationships between the use of the } \\
\text { document and parental under- } \\
\text { standing of essential elements of } \\
\text { informed consent }\end{array}$ & $\mathrm{x}$ & $\mathrm{x}$ & \\
\hline $\begin{array}{l}\text { Hoehn } \\
\text { et al. } 2005 \text { [64] }\end{array}$ & CSDS & $\begin{array}{l}\text { semistructured } \\
\text { interview }\end{array}$ & 34 & $\begin{array}{c}\text { Parents } \\
\text { (neonates) }\end{array}$ & $\begin{array}{l}\text { determine the reasons for parents' } \\
\text { decisions about participation in } \\
\text { research studies }\end{array}$ & & & $\mathrm{x}$ \\
\hline $\begin{array}{c}\text { John } \\
\text { et al. } 2008 \text { [19] }\end{array}$ & CSDS (RCT) & questionnaire & 73 & $\begin{array}{c}6.7 \text { to } 8 \\
\mathrm{M}=7.1 \\
\text { \& parents }\end{array}$ & $\begin{array}{l}\text { examine the quality of children's } \\
\text { assent to a clinical trial }\end{array}$ & $\mathrm{x}$ & & \\
\hline $\begin{array}{l}\text { Kodish } \\
\text { et al. } 2004 \text { [14] }\end{array}$ & CSDS (RCT) & $\begin{array}{l}\text { observation \& } \\
\text { interview }\end{array}$ & 137 & $\begin{array}{l}\text { Parents } \\
(1 \text { to } 18, \\
M=7.0)\end{array}$ & $\begin{array}{l}\text { observed explanations of randomi- } \\
\text { zation and parental understanding } \\
\text { of randomization after the consent } \\
\text { conference }\end{array}$ & $\mathrm{x}$ & & \\
\hline $\begin{array}{l}\text { Kodish } \\
\text { et al. } 1998 \text { [36] }\end{array}$ & $\begin{array}{l}\text { (a) CSDS } \\
\text { (b) CSDS }\end{array}$ & $\begin{array}{l}\text { (a) survey } \\
\text { (b) interview }\end{array}$ & $\begin{array}{l}\text { (a) } 82 \\
\text { (b) } 46\end{array}$ & $\begin{array}{l}\text { (a) PI \& RI } \\
\text { (b) Parents \& } \\
\text { researchers }\end{array}$ & $\begin{array}{l}\text { study of institutional practice with } \\
\text { regard to the informed consent } \\
\text { process }\end{array}$ & $\mathrm{x}$ & $\mathrm{x}$ & \\
\hline $\begin{array}{c}\text { Kupst } \\
\text { et al. } 2003 \text { [44] }\end{array}$ & CSDS & $\begin{array}{l}\text { semistructured } \\
\text { interview }\end{array}$ & 20 & $\begin{array}{l}\text { Parents } \\
(6 \text { to } 15 \text {, } \\
M=11.1)\end{array}$ & $\begin{array}{l}\text { evaluate the parents' levels of un- } \\
\text { derstanding about the treatment } \\
\text { trial and the quality of the parents' } \\
\text { consents to allow their children to } \\
\text { participate in the study }\end{array}$ & $\mathrm{x}$ & & \\
\hline $\begin{array}{c}\text { Levi } \\
\text { et al. } 2000 \text { [37] }\end{array}$ & FGS & focus groups & 22 & $\begin{array}{l}\text { Parents } \\
(2 \text { to } 18 \\
M=8.5)\end{array}$ & $\begin{array}{l}\text { describe retrospective perceptions } \\
\text { of parents of the circumstances of } \\
\text { their child's cancer diagnosis and } \\
\text { of the informed consent process }\end{array}$ & $\mathrm{x}$ & $\mathrm{X}$ & $\mathrm{x}$ \\
\hline $\begin{array}{l}\text { Mason \& } \\
\text { Allmark } 2000 \text { [49] }\end{array}$ & CSDS & $\begin{array}{l}\text { semistructured } \\
\text { interviews }\end{array}$ & $200 \& 107$ & $\begin{array}{c}\text { Parents } \\
\text { (neonates) \& } \\
\text { neonatologists }\end{array}$ & $\begin{array}{l}\text { whether the process of obtaining } \\
\text { informed consent from parents to } \\
\text { clinical trials on neonates leads to } \\
\text { valid consent }\end{array}$ & $\mathrm{x}$ & $\mathrm{x}$ & \\
\hline $\begin{array}{l}\text { Massimo \& Wiley } \\
2005 \text { [32] }\end{array}$ & $\mathrm{CS}$ & observation & 1 & 3 & $\begin{array}{l}\text { comment on the problems surfac- } \\
\text { ing in the informed consent process } \\
\text { for treatment and research in pedi- } \\
\text { atric oncology }\end{array}$ & $\mathrm{x}$ & $\mathrm{X}$ & \\
\hline McGrath 2002 [58] & CSDS & interview & 16 & $\begin{array}{l}\text { Parents } \\
(0 \text { to } 10)\end{array}$ & $\begin{array}{l}\text { report the perspective of parents } \\
\text { during the initial stages of diagno- } \\
\text { sis and treatment for their chil- } \\
\text { dren's acute lymphoblastic leuke- } \\
\text { mia }\end{array}$ & & $\mathrm{x}$ & \\
\hline
\end{tabular}


Morris et al. 2007 [15]

Morris et al. 2004 [57]

Olechnowicz et al. 2002 [53]

Ondrusek et al. 1998 [20]

Pletsch \& Stevens 2001 [66]

$$
\text { Reitamo }
$$
et al. 2008 [76]

Rothmier et al. 2003 [65]

Ruperto et al. 2010 [77]

Sammons et al. 2007 [59]
CSS (RCT)

observational and self-report assessment methods

Parents

(1 to 18 ,

$\mathrm{M}=7.2$ )

focus groups \& other material

$50 \& 75$

Family caregivers

CSDS

CSDS

interview \& questionnaire

semistructured interview

CSS

RS

semistructured

9

18

5 to 18

10 to 18

14

10

Mothers

CT

CSDS (RCT)

questionnaire

44

122

Parents

RCT medical screening

questionnaire identify barriers to parent understanding, this study assessed how aspects of clinician-parent communication during the informed consent conference (ICC) relate to $\quad \mathrm{x} \quad \mathrm{x}$ parent understanding of informed consent and parent perception of the impact of the ICC on their anxiety and control

(a) characterize parental perception of clinical research, particularly in emergency settings and (b) identify specific aspects of clinical research that concern parents and to discuss how these concerns can be addressed

(a) perform a community consultation and public disclosure process specific to a trial of induced hypothermia immediately after pediatric cardiac arrest and (b) determine the applicability of exception from informed consent to randomized, controlled trials of emergency interventions after resuscitation from inpatient pediatric cardiac arrest

examine the role of older children in discussing a recent diagnosis of acute leukemia and treatment options, including participation in a randomized, clinical trial (RCT)

compare the informed consent processes for phase III pediatric and adult oncology clinical trials

find answers to the following questions: How do mothers of children with diabetes make decisions about giving consent for their children to participate in research? What motivates mothers to keep their children in research once they are enrolled? How do mothers evaluate the clinical studies their children have participated in?

obtain information on the long-term safety and efficacy of $0.1 \%$ tacrolimus ointment

Parents \& define a group of factors that imguardians pact parental consent in the pediat(4 to 17) ric clinical trial

assess the long-term efficacy and safety of infliximab plus methotrexate in juvenile rheumatoid arthritis (JRA)

assess what motivates parents to consent to a randomised clinical trial (RCT), their feelings on consent and participation and the factors that would influence their decision to take part in a future study 


\section{Continued}

\begin{tabular}{|c|c|c|c|c|c|c|c|c|}
\hline $\begin{array}{l}\text { Scherer } \\
\text { et al. } 2005 \text { [63] }\end{array}$ & CSS & questionnaires & 36 & $\begin{array}{l}\text { Parents \& } \\
\text { adolescents } \\
\text { (11 to } 17 \text {, } \\
\mathrm{M}=13.2)\end{array}$ & $\begin{array}{l}\text { examine the impact of financial } \\
\text { compensation on pediatric asthma } \\
\text { research participation deci- } \\
\text { sion-making }\end{array}$ & & & $\mathrm{x}$ \\
\hline $\begin{array}{l}\text { Sederberg-Olsen et } \\
\text { al. } 1998 \text { [75] }\end{array}$ & RCT & medical screening & 360 & 1 to 10 & $\begin{array}{l}\text { evaluating the efficacy of amoxicil- } \\
\text { lin-clavulanate and penicillin- } \mathrm{V} \text { in } \\
\text { the treatment of secretory otitis } \\
\text { media }\end{array}$ & & & $\mathrm{x}$ \\
\hline $\begin{array}{l}\text { Simon et al. } 2006 \\
\text { [68] }\end{array}$ & CSS (RCT) & $\begin{array}{l}\text { observation \& } \\
\text { interview }\end{array}$ & 140 & $\begin{array}{l}\text { Parents } \\
(1 \text { to } 18 \\
M=7.0)\end{array}$ & $\begin{array}{l}\text { examine the role that altruistic } \\
\text { considerations play in participation }\end{array}$ & & & $\mathrm{x}$ \\
\hline $\begin{array}{l}\text { Simon et al. } 2004 \\
\text { [35] }\end{array}$ & CSS (RCT) & $\begin{array}{l}\text { observation \& } \\
\text { semistructured } \\
\text { interview }\end{array}$ & $140 \& 79$ & $\begin{array}{l}\text { Children } \\
\& \text { adults }\end{array}$ & $\begin{array}{l}\text { experiences giving informed } \\
\text { consent }\end{array}$ & $\mathrm{x}$ & $\mathrm{x}$ & \\
\hline $\begin{array}{l}\text { Simon et al. } 2003 \\
{[26]}\end{array}$ & CSS (RCT) & $\begin{array}{l}\text { observation \& } \\
\text { interview }\end{array}$ & 108 & Parents & $\begin{array}{l}\text { explores the pace of deci- } \\
\text { sion-making about trial participa- } \\
\text { tion within limited timeframes in } \\
\text { highly stressful circumstances }\end{array}$ & $\mathrm{x}$ & & \\
\hline $\begin{array}{l}\text { Singhal } \\
\text { et al. } 2002 \text { [34] }\end{array}$ & CSDS & questionnaire & 230 & $\begin{array}{c}\text { Parents } \\
\text { (newborns) }\end{array}$ & $\begin{array}{l}\text { examine beliefs and attitudes of } \\
\text { parents about research with babies }\end{array}$ & $\mathrm{x}$ & $\mathrm{x}$ & \\
\hline $\begin{array}{l}\text { Snowdon } \\
\text { et al. } 2006 \text { [41] }\end{array}$ & CSDS (RCT) & interview & 78 & Parents (babies) & $\begin{array}{l}\text { explore the pace of deci- } \\
\text { sion-making for } 78 \text { parents } \\
\text { associated with one or more of four } \\
\text { such trials in the UK }\end{array}$ & $\mathrm{x}$ & $\mathrm{x}$ & $\mathrm{x}$ \\
\hline $\begin{array}{l}\text { Snowdon } \\
\text { et al. } 1998 \text { [71] }\end{array}$ & CSDS (RCT) & interview & 24 & Parents (babies) & $\begin{array}{l}\text { assess views of parents of babies } \\
\text { who participated in a neonatal trial, } \\
\text { about feedback of trial } \\
\text { results }\end{array}$ & & & $\mathrm{x}$ \\
\hline $\begin{array}{l}\text { Stenson } \\
\text { et al. } 2004 \text { [50] }\end{array}$ & CSDS (RCT) & questionnaire & 99 & $\begin{array}{l}\text { Parents } \\
\text { (neonates) }\end{array}$ & $\begin{array}{l}\text { investigate the recollections of } \\
\text { parents consenting for their infants } \\
\text { to be research subjects and deter- } \\
\text { mine their views about the need for } \\
\text { consent }\end{array}$ & $\mathrm{x}$ & & \\
\hline $\begin{array}{c}\text { Stevens \& } \\
\text { Pletsch } 2002[38]\end{array}$ & CSDS & interview & 12 & $\begin{array}{l}\text { Mothers } \\
(9 \text { to } 20 \\
M=13.9)\end{array}$ & $\begin{array}{l}\text { describe how parents were intro- } \\
\text { duced to bone marrow transplanta- } \\
\text { tion as a course of action to treat } \\
\text { their gravely ill children, what their } \\
\text { understanding of the protocol was, } \\
\text { and the process by which they gave } \\
\text { their consent }\end{array}$ & $\mathrm{x}$ & $\mathrm{x}$ & \\
\hline $\begin{array}{l}\text { Stuijvenberg } \\
\text { et al. } 1998 \text { [61] }\end{array}$ & CSS (RCT) & questionnaire & 181 & $\begin{array}{l}\text { Parents } \\
(1 \text { to } 4)\end{array}$ & $\begin{array}{l}\text { assess the quality of the informed } \\
\text { consent process in a paediatric } \\
\text { setting }\end{array}$ & & $\mathrm{x}$ & $x$ \\
\hline $\begin{array}{c}\text { Tait } \\
\text { et al. } 2007[21]\end{array}$ & RT & interview & 190 & 7 to 17 & $\begin{array}{l}\text { examine the effect of improved } \\
\text { readability and processability of } \\
\text { written study information on chil- } \\
\text { drens' understanding }\end{array}$ & $\mathrm{x}$ & & \\
\hline $\begin{array}{c}\text { Tait } \\
\text { et al. } 2005[28]\end{array}$ & RCT & $\begin{array}{l}\text { semistructured } \\
\text { interview, } \\
\text { questionnaire } \\
\text { \& tests }\end{array}$ & 305 & $\begin{array}{l}\text { Parents } \\
\text { (0 to } 17)\end{array}$ & $\begin{array}{l}\text { examine whether a consent docu- } \\
\text { ment modified to conform with the } \\
\text { federal guidelines for readability } \\
\text { and processability would result in } \\
\text { greater parental understanding } \\
\text { compared with a standard form }\end{array}$ & $\mathrm{x}$ & & \\
\hline $\begin{array}{l}\text { Tait } \\
\text { et al. } 2004 \text { [40] }\end{array}$ & CSS (RCT) & questionnaire & 505 & $\begin{array}{l}\text { Parents } \\
(\mathrm{M}=7.2)\end{array}$ & $\begin{array}{l}\text { examine factors that influence } \\
\text { parents' assessments of the risks } \\
\text { and benefits of anesthesia and } \\
\text { surgery research involving their } \\
\text { children }\end{array}$ & $\mathrm{x}$ & & $\mathrm{x}$ \\
\hline
\end{tabular}




\section{Continued}

\begin{tabular}{|c|c|c|c|c|c|c|c|c|}
\hline $\begin{array}{c}\text { Tait } \\
\text { et al. } 2003 \text { [17] }\end{array}$ & CSS (RCT) & $\begin{array}{l}\text { semistructured } \\
\text { interview }\end{array}$ & 102 & 7 to 18 & $\begin{array}{l}\text { determine children's understanding } \\
\text { of the elements of disclosure for } \\
\text { studies in which they had assented } \\
\text { to participate }\end{array}$ & $\mathrm{x}$ & & \\
\hline $\begin{array}{c}\text { Tercyak } \\
\text { et al. } 1998 \text { [73] }\end{array}$ & CSS & $\begin{array}{l}\text { semistructured } \\
\text { interview }\end{array}$ & 99 & 11 to 18 & $\begin{array}{l}\text { (a) identify reasons adolescents } \\
\text { refuse to participate in a random- } \\
\text { ized trial of intensive therapy, (b) } \\
\text { describe the patient characteristics } \\
\text { of those who consent and those } \\
\text { who refuse to participate, and (c) } \\
\text { examine recruiter effects on trial } \\
\text { participation rates }\end{array}$ & & & $\mathrm{x}$ \\
\hline $\begin{array}{c}\text { Unguru } \\
\text { et al. } 2010 \text { [24] }\end{array}$ & CSS & $\begin{array}{c}\text { Interview \& } \\
\text { questionnaire }\end{array}$ & 37 & 7 to 18 & $\begin{array}{l}\text { examine what children with cancer } \\
\text { understand about research, their } \\
\text { research-related treatment, and } \\
\text { their preferences for inclusion in } \\
\text { decision-making }\end{array}$ & $\mathrm{x}$ & $\mathrm{X}$ & \\
\hline $\begin{array}{c}\text { Varma } \\
\text { et al. } 2008[51]\end{array}$ & CSS & $\begin{array}{l}\text { structured } \\
\text { interview }\end{array}$ & 91 dyads & $\begin{array}{l}7 \text { to } 14 \& \\
\text { Parents / } \\
\text { guardians }\end{array}$ & $\begin{array}{l}\text { examine how children and parents } \\
\text { make decisions regarding pediatric } \\
\text { research }\end{array}$ & & $\mathrm{X}$ & $\mathrm{X}$ \\
\hline $\begin{array}{c}\text { Wagner } \\
\text { et al. } 2006 \text { [60] }\end{array}$ & CSDS (RCT) & questionnaires & 90 dyads & $\begin{array}{l}6 \text { to } 17, \\
\mathrm{M}=12.3 \\
\text { \& parents }\end{array}$ & $\begin{array}{l}\text { assess youths' and their parents' } \\
\text { attitudes and experiences about } \\
\text { participation in clinical treatment } \\
\text { research }\end{array}$ & & $\mathrm{x}$ & $\mathrm{x}$ \\
\hline $\begin{array}{c}\text { Wiley } \\
\text { et al. } 1999 \text { [46] }\end{array}$ & CCS (RCT) & questionnaire & 192 & Parents & $\begin{array}{l}\text { investigate parents' knowledge and } \\
\text { perceptions about randomization in } \\
\text { clinical trials for children with } \\
\text { cancer, and to determine whether } \\
\text { parents' decisions were influenced } \\
\text { by demographic factors, randomi- } \\
\text { zation circumstances, the clinical } \\
\text { characteristics of the child with } \\
\text { cancer, or a combination }\end{array}$ & $\mathrm{x}$ & & \\
\hline $\begin{array}{c}\text { Zupancic } \\
\text { et al. } 1997 \text { [67] }\end{array}$ & CSS (RCT) & questionnaire & 140 & $\begin{array}{c}\text { Parents } \\
\text { (neonates) }\end{array}$ & $\begin{array}{l}\text { determine the degree to which such } \\
\text { parental decisions are influenced } \\
\text { by risk and benefit considerations } \\
\text { compared with other factors }\end{array}$ & & & $\mathrm{x}$ \\
\hline
\end{tabular}

1“(RCT)”: This study recruits participants from an underlying randomized clinical trial [RCT]; CCS: Case control study; CS: Case study; CSS: Cross-sectional study; CSDS: Cross-sectional descriptive study; CT: Clinical Trial; FGS: Focus group study; LS: Longitudinal study; RCT: Randomized clinical trial; RT: Randomized Trial; RS: retrospective study. 